Article

\title{
Effects of Multivitamin, Multimineral and Phytonutrient Supplementation on Nutrient Status and Biomarkers of Heart Health Risk in a Russian Population: A Randomized, Double Blind, Placebo Controlled Study
}

\author{
Vasily A. Isakov ${ }^{1, *(1)}$, Alexandra A. Bogdanova ${ }^{1}$, Vladimir V. Bessonov ${ }^{1}$, Tatiana B. Sentsova ${ }^{1}$, \\ Victor A. Tutelyan ${ }^{1}$, Yumei Lin ${ }^{2}$, Valentina Kazlova ${ }^{2}$, Jina Hong ${ }^{2, *}$ (D) and Rodney A. Velliquette ${ }^{2}$ \\ 1 Institute of Nutrition, Ustinsky Proezd, 2/14, Moscow 109240, Russia; alex.golubeva@gmail.com (A.A.B.); \\ bessonov@ion.ru (V.V.B.); bio45@inbox.ru (T.B.S.); tutelyan@ion.ru (V.A.T.) \\ 2 Access Business Group International, LLC, 5600 Beach Blvd., Buena Park, CA 90621, USA; \\ ylin@yumeiconsulting.com (Y.L.); valentina.kazlova@amway.com (V.K.); \\ rod.velliquette@amway.com (R.A.V.) \\ * Correspondence: vasily.isakov@gmail.com (V.A.I.); jina.hong@amway.com (J.H.); \\ Tel.: +7-499-613-0764 (V.A.I.); +1-714-562-7851 (J.H.)
}

Received: 7 November 2017; Accepted: 23 January 2018; Published: 25 January 2018

\begin{abstract}
The primary objective of this clinical study was to evaluate the effect of a dietary multivitamin, multimineral and phytonutrient (VMP) supplement on blood nutrient status and biomarkers of heart health risk in a Russian population. One hundred twenty healthy adults (40-70 years) were recruited for a 56-day (eight-week) randomized, double blind, placebo controlled study with parallel design. Subjects were divided into two groups and received either a VMP or a placebo (PLA) supplement. Blood nutrient levels of $\beta$-carotene, $\alpha$-tocopherol, vitamin $C$, B6, B12, red blood cell (RBC) folate, Zinc and Selenium were measured at baseline and on Days 28 and 56, and quercetin was measured at baseline and on Day 56. Blood biomarkers of heart health, i.e. homocysteine (Hcy), high-sensitivity C-reactive protein (hs-CRP), oxidized LDL (ox-LDL), gamma-glutamyl transferase (GGT), uric acid and blood lipid profile, were measured at baseline and Day 56. Dietary VMP supplementation for 56 days significantly increased circulating levels of quercetin, vitamin C, RBC folate and partially prevented the decline in vitamin B6 and B12 status. Both serum Hcy and GGT were significantly reduced $(-3.97 \pm 10.09 \mu \mathrm{mol} / \mathrm{L} ;-1.68 \pm 14.53 \mathrm{U} / \mathrm{L}$, respectively) after VMP supplementation compared to baseline. Dietary VMP supplementation improved the nutrient status and reduced biomarkers of heart health risk in a Russian population.
\end{abstract}

Keywords: heart health risk; homocysteine; nutrient status; dietary supplementation; quercetin; multivitamin; multimineral; phytonutrient

\section{Introduction}

A fruit and vegetable rich diet is associated with reduced risk for chronic diseases such as cardiovascular disease (CVD) [1]. Fruits and vegetables are natural source of vitamins, minerals and phytonutrients (phytochemicals, which have a positive effect on human health), and some of these components have been reported to have antioxidant and cardioprotective effects in clinical trials [2-4]. However, randomized, double blind, placebo controlled trials examining whether phytonutrients have protective effects against the development of CVD are still lacking.

A poor antioxidant defense status can promote the generation of free radicals, which have been reported to be positively correlated with blood homocysteine (Hcy) levels [5,6]. Elevated Hcy 
concentration is thought to be a risk factor for CVD and may accelerate the progression and the initial incidence of arteriosclerosis via free radical generation [7]. In addition to antioxidant intake and defense status, dietary folate, vitamin B6 and vitamin B12 intake, gender and age can impact blood Hcy levels [8-10]. Multiple lifestyle behaviors also influence chronic disease development. Studies have shown that lower serum antioxidants levels are present in smokers compared to non-smokers [11,12]. Alcohol consumption is high in Russian population and low levels of antioxidants have been found in chronic drinkers and evidence suggests an inverse relationship between antioxidant status and CVD [13].

Data from the Moscow Behavioral Risk Factor Survey (2000-2001) indicated the mean fruit and vegetable intake in men and women in Moscow was much lower (190 g/day) than the World Health Organization's recommended 400 g/day [14,15]. The World Health Survey (2002-2003) data indicated that approximately $80 \%$ of Russians consumed lower than the WHO recommended levels [16]. Using data from the Health in Times of Transition data set (2010), Goryakin et al. reported that only $42.7 \%$ of Russia adults consumed fruits and vegetables daily or several times weekly [17]. Together, these data strongly suggest that Russian adults consume far below the World Health Organization (WHO)'s recommendation for fruits and vegetable intake. This lower than recommended intake would likely lead to lower intake of vitamins, minerals and phytonutrients, which could lead to higher risks for chronic diseases such as CVD [18]. Therefore, promoting healthy dietary and lifestyles behaviors, and supplementing for deficiencies becomes a critical approach in preventing chronic disease development.

In this clinical study, we examined whether a multivitamin, multimineral and phytonutrient product could improve the nutritional status and reduce biomarkers of heart health risk in a Russian population with low fruit and vegetable intake. The primary outcome of the study was to evaluate the effect of a multivitamin, multimineral and phytonutrient (VMP) product on nutrient status and biomarkers of heart health risk factors; and secondary outcome was to test the safety and tolerability of a VMP product.

\section{Materials and Methods}

\subsection{Study Population and Design}

The study was 56-day (eight-week) randomized, double blind, placebo controlled clinical trial. One hundred twenty generally healthy (without chronic diseases) adults (40-70 years) from Moscow, Russia were recruited. Subjects had habitually low dietary intake of recommended foods, predominantly fruit and vegetable, as classified by a recommended food score (RFS) of $<12$ (score range, 0-23). The RFS is based on consumption of recommended foods in a 62-item Food Frequency Questionnaire (FFQ) with modifications according to availability of food items in the Russia area [19] (see Appendix A for list of foods). Subjects were randomized to either receive a placebo (PLA) $(n=60)$ or VMP $(n=60)$ supplement (Figure 1$)$. The study was conducted at the Institute of Nutrition of Russian Academy of Medical Sciences and followed the Good Clinical Practice guidelines and the Declaration of Helsinki (1996). The study was approved by the Institute of Nutrition IRB (Moscow, Russia) according to Good Clinical Practice and Helsinki Declaration (Sixth revision, 2008). Table 1 shows the inclusion and exclusion criteria for subjects, and Table 2 illustrates the summary of study visits and procedures. This study was registered at ClinicalTrials.gov (NCT02224092). 
Web/Media information about the study given, volunteers responded via e-mail/phone $(n=310)$

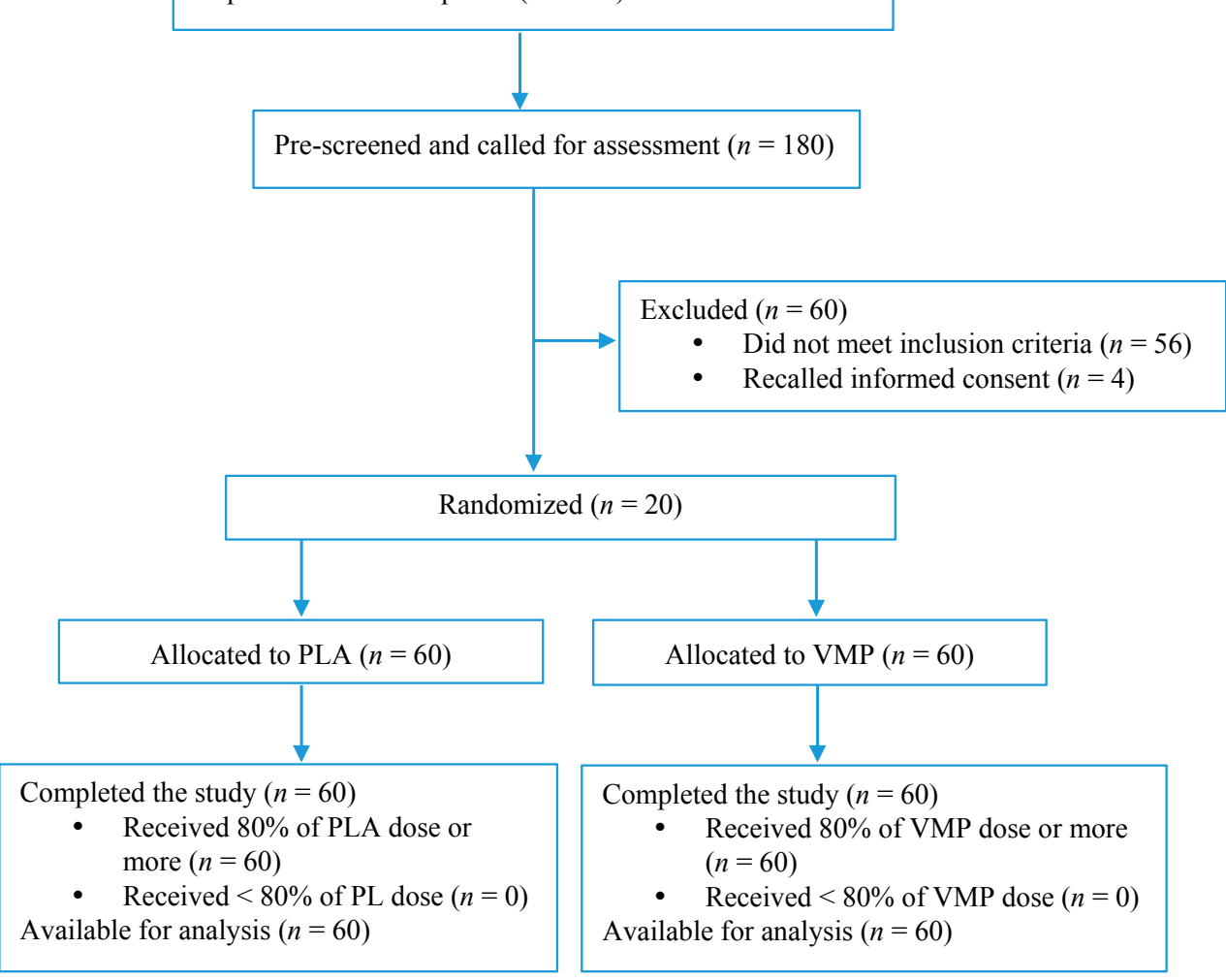

Figure 1. Consort diagram summarizing the subjects disposition for the study.

Table 1. Study inclusion and exclusion criteria.

\begin{tabular}{|c|}
\hline Inclusi \\
\hline $\begin{array}{l}\text { Generally healthy men and women aged from } 40 \text { to } 70 \text { years of age preferable smokers and who regularly consumes } \\
\text { alcohol, and consuming fewer than } 12 \text { items found on the Recommended Foods Checklist (see below) per week. }\end{array}$ \\
\hline Individual should be judged to be in good general health based on an interview and abbreviated physical exam. \\
\hline Individual understands the procedures and agrees to participate in the study. \\
\hline Individual is able and willing to provide written informed consent and confidentiality agreement. \\
\hline Exclusion Criteria: \\
\hline $\begin{array}{l}\text { Use of dietary supplements within one week of Day } 1 \text {. Supplements include any vitamins, minerals, and herbal } \\
\text { products, including herbal drinks. }\end{array}$ \\
\hline $\begin{array}{l}\text { Presence of cardiovascular disease, hypercholesterolemia, cancer, diabetes mellitus, or any other chronic health } \\
\text { condition identified from the findings of the interview. }\end{array}$ \\
\hline $\begin{array}{l}\text { Currently treated for uncontrolled hypertension or blood pressure greater }>140 \mathrm{~mm} \mathrm{Hg} \text { systolic or }>90 \mathrm{~mm} \mathrm{Hg} \\
\text { diastolic during seated, resting measurement on two consecutive occasions during visit } 1 \text {. }\end{array}$ \\
\hline Therapeutic uses of coumadin, aspirin, or other medications that influence hemostasis within four weeks of Day 1. \\
\hline Participation in another clinical trial within 30 days of enrollment into the study. \\
\hline History or current abuse of drugs or alcohol, or intake $>4$ alcoholic beverages per day. \\
\hline Known hypersensitivity to study product or any ingredient in study product. \\
\hline $\begin{array}{l}\text { A change in hormone therapy, including oral contraceptives, within } 4 \text { weeks prior to screening, or unwilling to } \\
\text { maintain current hormone therapy/oral contraceptive use throughout the course of the study. }\end{array}$ \\
\hline $\begin{array}{l}\text { Pregnant or lactating women, or pre-menopausal women not using a medically approved form of birth control. } \\
\text { Any condition that the Principal Investigators believe may put the subject at undue risk. }\end{array}$ \\
\hline
\end{tabular}


Table 2. Summary of study time line and measurements.

\begin{tabular}{|c|c|c|c|c|c|c|c|}
\hline Study Measurements & $\begin{array}{l}\text { Office } \\
\text { Visit } 1\end{array}$ & $\begin{array}{l}\text { Office } \\
\text { Visit } 2\end{array}$ & $\begin{array}{l}\text { Office } \\
\text { Visit } 3\end{array}$ & $\begin{array}{l}\text { Office } \\
\text { Visit } 4\end{array}$ & $\begin{array}{l}\text { Office } \\
\text { Visit } 5\end{array}$ & $\begin{array}{l}\text { Office } \\
\text { Visit } 6\end{array}$ & $\begin{array}{l}\text { Phone } \\
\text { Interview }\end{array}$ \\
\hline & Day 0 & Day 1 & Day 14 & Day 28 & Day 42 & Day 56 & Day $57-60$ \\
\hline Informed Consent & $x$ & & & & & & \\
\hline Pregnancy test (urine) & $x$ & & & & & & \\
\hline Recommended Foods Checklist & $x$ & & & & & $x$ & \\
\hline Physical Exam & $x$ & & & & & $x$ & \\
\hline $\begin{array}{l}\text { Medical History, Family Medical } \\
\text { History, Dietary Behavior and } \\
\text { Lifestyle Questionnaires }\end{array}$ & $\mathrm{X}$ & & & & & $\mathrm{X}$ & \\
\hline Food Frequency Questionnaire & $x$ & & & & & $x$ & \\
\hline Blood lipid profile determination & $x$ & & & & & $x$ & \\
\hline $\begin{array}{l}\text { Blood concentrations of selected } \\
\text { nutrients determined }\end{array}$ & $\mathrm{x}$ & & & $\mathrm{x}$ & & $\mathrm{x}$ & \\
\hline $\begin{array}{l}\text { Biomarkers of Heart health } \\
\text { risk determined }\end{array}$ & $\mathrm{X}$ & & & & & $x$ & \\
\hline $\begin{array}{l}\text { Safety measurements (Serum } \\
\text { Chemistry Panel, Hematology, } \\
\text { and Urinalysis) }\end{array}$ & $\mathrm{x}$ & & & & & & \\
\hline Adverse Events Questionnaire & & $x$ & $x$ & $x$ & $x$ & $x$ & $x$ \\
\hline Inform subject's eligibility & & $x$ & & & & & \\
\hline Follow-up as Good Clinical Practice & & & & & & & $x$ \\
\hline Dispense the product & & $x$ & & $x$ & & & \\
\hline Collect the product & & & $x$ & $x$ & $x$ & $x$ & \\
\hline
\end{tabular}

\subsection{Study Samples}

There were two study samples: (1) a VMP; and (2) a PLA. Each sample contained three different types of tablets; (1) a vitamin; (2) a mineral; and (3) a phytonutrient. The VMP sample (six Nutrilite Double $X^{\mathrm{TM}}$ tablets) provides the following micronutrients daily: 14 vitamins (800 $\mu \mathrm{g}$ Vit A, $5.0 \mu \mathrm{g}$ Vit D, 16 mg Vit E, 55 g Vit K, 2.0 mg Vit B1, 2.4 mg Vit B2, 3.0 mg Vit B6, $2.0 \mu \mathrm{g}$ Vit B12, $180 \mathrm{mg}$ Vit C, $26 \mathrm{mg}$ niacin, $60 \mu \mathrm{g}$ biotin, $3.0 \mathrm{mg} \beta$-carotene, $400 \mu \mathrm{g}$ folate and $10 \mathrm{mg}$ pantothenic acid), nine minerals (471 mg calcium, $5.0 \mathrm{mg}$ iron, $37.5 \mu \mathrm{g}$ iodine, $6 \mathrm{mg}$ zinc, $0.75 \mathrm{mg}$ copper, $1 \mathrm{mg}$ manganese, $55 \mathrm{mg}$ magnesium, $25 \mu \mathrm{g}$ chromium and $50 \mu \mathrm{g}$ selenium) and the phytonutrient tablet contained apple, bilberry, grape seeds, plum, pomegranate, cranberry juice, grape and rosemary extracts, and parsley, carrot, broccoli, spinach and horseradish powders. The PLA sample for this trial was formulated to match the shape and color of all VMP sample tablets, e.g., a vitamin placebo, a mineral placebo and a phytonutrient placebo. PLA sample contained dextrose (or maltodextrin), microcrystalline cellulose, croscarmellose sodium and magnesium stearate. All tablets were manufactured in a Good Manufacture Practice certified facility, Access Business Group International, LLC (Buena Park, CA, USA).

Subjects were instructed to consume study samples twice a day, once in the morning and once in evening with meal (6 tablets/day). To ensure compliance, each serving was packed in an individual sachet and a monthly supply was provided to participants. The directions for consumption of the different study samples were printed on the bag. Compliance was assessed by counting the number of tablets at each visit and patients were considered compliant if they took $80 \%$ or more of total number of VMP or PLA samples. Blood samples were collected from all subjects during office visits at baseline (Day 1 prior to consuming study samples), Day 28 and Day 56. All samples were stored at $-80{ }^{\circ} \mathrm{C}$ until analysis. 


\subsection{Questionnaires}

Dietary macro- and micronutrients intake were determined using a PC-based FFQ (FFQ-1.0, Institute of Nutrition, Moscow, Russia) validated earlier in patients with different diseases as well as healthy Russian population [20]. A questionnaire on medical history, family medical history, smoking habits and history, alcohol consumption habits and history, exercise habits and dietary supplement use (current and history) was also administered to all subjects.

\subsection{Nutrient Analysis}

Blood samples were taken in fasting condition according to protocol (Table 2). Serum $\beta$-carotene and total tocopherols (alpha- and gammatocopherol) were assessed simultaneously by isocratic rapid High Performance Liquid Chromatography (HPLC) [21]. In brief, $200 \mu \mathrm{L}$ of serum was deproteinated by the addition of $200 \mu \mathrm{L}$ ethyl alcohol containing $0.5 \mu \mathrm{mol} / \mathrm{L}$ echinenone and $4 \mu \mathrm{mol} / \mathrm{L}$ tocol with $30 \mathrm{mg} / \mathrm{L}$ butylated hydroxytoluen. The samples were vortexed for $2 \mathrm{~min}$, followed by addition of $800 \mu \mathrm{L}$ hexane and centrifuged for $10 \mathrm{~min}$ at $1500 \mathrm{rpm}$. The hexane extraction process was repeated, and the supernatants were combined and evaporated under nitrogen. The residues were dissolved in $100 \mu \mathrm{L}$ mobile phase, containing $30 \mathrm{mg} / \mathrm{L}$ BHT and $20 \mu \mathrm{L}$ was injected into an Agilent 1100 HPLC system (Agilent Technologies, Waldbronn, Germany) equipped with diode array detector (DAD) and fluorescence detector (FLD). A Javelin guard column $(3 \mathrm{~mm} \times 20 \mathrm{~mm}$, Spherisorb ODS2 $3 \mu \mathrm{m}$ (C18)) connected to Thermo Spherisorb ODS2 column $(3 \mathrm{~mm} \times 250 \mathrm{~mm}, 3 \mu \mathrm{m})$ (Fisher Scientific UK Ltd., Loughborough, UK) was used. The DAD detector was adjusted at $455 \mathrm{~nm}$ for the $\beta$-carotene. FLD detector was configured at $\lambda \mathrm{ex}=290 \mathrm{~nm}$ and $\lambda \mathrm{em}=335 \mathrm{~nm}$ for the tocopherols. Standards of $\beta$-carotene, and tocopherols were obtained from Sigma-Aldrich (St. Louis, MO, USA).

Plasma vitamin (Vit) C, B6, B12 and red blood cells (RBC) folate measurement were performed using enzyme immunoassay (EIA) kits according to manufacturer instructions (BCM Diagnostics, Moscow, Russia). Total plasma selenium was determined by simplified fluorometric assay [22]. Serum zinc level was assessed by indirect colorimetry using QuantiChrom ${ }^{\mathrm{TM}}$ Zinc kit per manufacturer instructions (BioAssay Systems, Hayward, CA, USA). Blood calcium, magnesium and iron were assessed by turbidimetry using automated analyzer Konelab 30i (Thermo Fisher Scientific Messtechnik $\mathrm{GmbH}$, Oberhausen, Germany). Plasma quercetin concentration was measured by HPLC/MS (Agilent 1200; Mass Spectrometer: Agilent Triple Quad 6410, Agilent Technologies, Waldbronn, Germany) after treatment with a beta-glucuronidase/sulfatase mixture and extraction into ethylacetate as described previously [23].

\subsection{Biomarkers of Heart Health Risk}

Blood total cholesterol, high-density lipoprotein (HDL), low-density lipoprotein (LDL), gamma-glutamyl transferase (GGT), and triglycerides were assessed by turbidimetry using automated analyzer Konelab 30i (Thermo Fisher Scientific Messtechnik GmbH, Oberhausen, Germany). Total serum homocysteine level was assessed by using Axis Homocysteine EIA kit (Axis-Shield Diagnostics Ltd., Dundee, UK). Briefly, protein-bound homocysteine was reduced to free homocysteine and enzymatically converted to $S$-adenosyl-L-homocysteine in a separate procedure prior to the immunoassay, according to manufacturer instruction. Serum high sensitivity C-reactive protein (hs-CRP) was assessed by using EIA kit (Diagnostics Biochem Canada Inc., Dorchester, ON, Canada) per manufacturer instructions. Serum oxidized LDL (ox-LDL) concentration was measured with an ox-LDL EIA kit (Biomedica Medizinprodukte GmbH, Wien, Austria) per manufacturer instructions.

Safety and tolerability of study samples was assessed by measuring changes in serum chemistry, hematology, vital signs and body weight. Potential study sample related adverse events (AE) were assessed by a self-reported questionnaire during follow up phone interview (Table 2). 


\subsection{Data Analysis}

Statistical analysis was done with Statistica 6.0 software by StatSoft (Tulsa, OK, USA). Graphical method (histograms) and non-parametrical test of Kolmogorov-Smirnov were used to verify the distribution of interval variables. Methods of parametric and non-parametric statistics were used based on the variables type and distribution and the number of controls. Student's T-test and Mann-Whitney criteria were used to estimate the rate of differences between 2 independent selections. Student's T-test and Wilcoxon's criteria were used to estimate the rate of differences between 2 co-dependent selections. $\chi^{2}$ criteria or Fishers double-sided criteria was used to estimate reliability of quality parameters distribution. Benjamini-Hochberg procedure was used to control the False Discovery Rate (FDR) when performing multiple comparisons. Data are presented as mean value \pm standard deviation except where dichotomized data is presented.

\section{Results}

Subjects were healthy, had no medical conditions or complaints, and were not receiving any medical treatment or consuming dietary supplements containing vitamins, minerals or herbals ingredients. All randomized subjects completed the protocol, no drop-outs were registered (Figure 1). Table 3 shows subjects baseline characteristics, lifestyle behaviors and biomarkers of heart health risk. Subjects were predominantly women, but there was no difference in gender between two studied groups. There were no significant differences between groups in any of the measurements, however, both groups on average were overweight and had elevated serum Hcy levels ( $>15 \mu \mathrm{mol} / \mathrm{L})$. In addition, there were no significant differences in nutrient consumption and blood nutrient status between groups at baseline (Table 4). However, excess consumption of fats and sodium were indicated from FFQ in both groups.

Table 3. Subjects baseline characteristics.

\begin{tabular}{|c|c|c|c|}
\hline Variable & PLA Group $(n=60)$ & VMP Group $(n=60)$ & $p$-Value \\
\hline Male/Female $(n)$ & $9 / 51$ & $12 / 48$ & 0.630 \\
\hline Age (year) & $48.9 \pm 7.6$ & $49.5 \pm 7.6$ & 0.660 \\
\hline Smokers, $(n)(\%)$ & $14(23 \%)$ & $16(27 \%)$ & 0.830 \\
\hline Alcohol consumers, $(n)(\%)$ & $39(65 \%)$ & $30(50 \%)$ & 0.140 \\
\hline Physically active, $(n)(\%)$ & $26(43 \%)$ & $22(36 \%)$ & 0.580 \\
\hline \multicolumn{4}{|l|}{ Anthropomorphic Measurement } \\
\hline Weight $(\mathrm{kg})$ & $74.27 \pm 15.94$ & $75.72 \pm 15.47$ & 0.615 \\
\hline $\operatorname{BMI}\left(\mathrm{kg} / \mathrm{m}^{2}\right)$ & $26.58 \pm 5.72$ & $26.89 \pm 4.92$ & 0.739 \\
\hline Waist/Hip ratio & $0.87 \pm 0.13$ & $0.88 \pm 0.15$ & 0.516 \\
\hline Systolic blood pressure $(\mathrm{mmHg})$ & $116.30 \pm 9.05$ & $117.83 \pm 9.76$ & 0.374 \\
\hline Diastolic blood pressure (mmHg) & $75.08 \pm 8.49$ & $75.58 \pm 6.89$ & 0.724 \\
\hline \multicolumn{4}{|l|}{ Heart Health Biomarkers } \\
\hline Homocysteine $(\mu \mathrm{mol} / \mathrm{L})$ & $15.98 \pm 6.62$ & $18.55 \pm 10.53$ & 0.112 \\
\hline hs-CRP (ng/mL) & $1922 \pm 1937$ & $2551 \pm 2594$ & 0.135 \\
\hline Oxidized LDL (ng/mL) & $3939 \pm 4109$ & $3546 \pm 3011$ & 0.552 \\
\hline GGT $(\mathrm{U} / \mathrm{L})$ & $22.41 \pm 12.62$ & $26.18 \pm 18.71$ & 0.199 \\
\hline Uric acid $(\mu \mathrm{mol} / \mathrm{L})$ & $236 \pm 83$ & $241 \pm 68$ & 0.725 \\
\hline Total Cholesterol (mmol/L) & $5.13 \pm 0.93$ & $5.10 \pm 1.02$ & 0.863 \\
\hline HDL cholesterol (mmol/L) & $1.61 \pm 0.46$ & $1.57 \pm 0.41$ & 0.571 \\
\hline LDL cholesterol (mmol/L) & $3.37 \pm 0.76$ & $3.29 \pm 0.80$ & 0.590 \\
\hline Triglycerides (mmol/L) & $1.04 \pm 0.58$ & $1.06 \pm 0.66$ & 0.818 \\
\hline
\end{tabular}

Values expressed as mean \pm S.D. BMI = body mass index; PLA = placebo; multivitamin, VMP = multimineral and phytonutrient; hs-CRP = high-sensitivity C-reactive protein; LDL = low-density lipoprotein; GGT = gamma-glutamyl transferase; HDL = high-density lipoprotein. 
Table 4. Baseline dietary intake from food frequency questionnaire and blood nutrient levels.

\begin{tabular}{|c|c|c|c|}
\hline Variable & PLA Group & VMP Group & $p$-Value \\
\hline RFS & $8.8 \pm 1.3$ & $8.8 \pm 1.3$ & 0.943 \\
\hline Calories (kcal/day) & $2449 \pm 759$ & $2481 \pm 828$ & 0.825 \\
\hline Protein (g/day) & $87 \pm 31$ & $85 \pm 37$ & 0.712 \\
\hline Carbohydrate (g/day) & $220 \pm 100$ & $244 \pm 130$ & 0.252 \\
\hline Sugar (g/day) & $64 \pm 52$ & $74 \pm 69$ & 0.352 \\
\hline Fat (g/day) & $117 \pm 44$ & $117 \pm 47$ & 0.999 \\
\hline Saturated fat (g/day) & $39 \pm 16$ & $39 \pm 14$ & 0.842 \\
\hline Polyunsaturated fat (g/day) & $28 \pm 15$ & $27 \pm 15$ & 0.800 \\
\hline$\omega-6$ (g/day) & $25 \pm 14$ & $25 \pm 14$ & 0.936 \\
\hline$\omega-3$ (g/day) & $3.2 \pm 1.5$ & $3.0 \pm 1.6$ & 0.544 \\
\hline Cholesterol (mg/day) & $266 \pm 137$ & $281 \pm 208$ & 0.636 \\
\hline $\mathrm{Na}$ (mg/day) & $3888 \pm 1532$ & $3805 \pm 1660$ & 0.777 \\
\hline $\mathrm{K}$ (mg/day) & $3643 \pm 1709$ & $3515 \pm 1691$ & 0.682 \\
\hline $\mathrm{Ca}$ (mg/day) & $1137 \pm 480$ & $1147 \pm 515$ & 0.913 \\
\hline $\mathrm{P}$ (mg/day) & $1520 \pm 496$ & $1512 \pm 575$ & 0.929 \\
\hline $\mathrm{Mg}$ (mg/day) & $378 \pm 144$ & $378 \pm 167$ & 0.986 \\
\hline $\mathrm{Fe}$ (mg/day) & $17.8 \pm 8.6$ & $17.61 \pm 9.77$ & 0.893 \\
\hline Vit A (mg/day) & $0.34 \pm 0.24$ & $0.42 \pm 0.24$ & 0.090 \\
\hline Vit B1 (mg/day) & $1.03 \pm 0.42$ & $1.06 \pm 0.55$ & 0.720 \\
\hline Vit B2 (mg/day) & $1.57 \pm 0.56$ & $1.61 \pm 0.70$ & 0.736 \\
\hline Niacin (mg/day) & $15.0 \pm 6.8$ & $14.7 \pm 7.4$ & 0.821 \\
\hline Vit C (mg/day) & $191 \pm 147$ & $187 \pm 137$ & 0.874 \\
\hline \multicolumn{4}{|l|}{ Blood Nutrients } \\
\hline$\beta$-Carotene $(\mu \mathrm{g} / \mathrm{dL})$ & $138 \pm 66$ & $133 \pm 54$ & 0.662 \\
\hline Total tocopherols (mg/dL) & $1.88 \pm 0.43$ & $1.87 \pm 0.48$ & 0.872 \\
\hline Vit C (mg/dL) & $11.76 \pm 8.68$ & $9.66 \pm 8.07$ & 0.173 \\
\hline RBC Folate $(\mu \mathrm{g} / \mathrm{L})$ & $7.24 \pm 2.98$ & $7.10 \pm 3.04$ & 0.798 \\
\hline Vit B6 $(\mu \mathrm{g} / \mathrm{L})$ & $12.7 \pm 5.1$ & $11.6 \pm 5.2$ & 0.277 \\
\hline Vit B12 (ng/mL) & $332 \pm 174$ & $339 \pm 215$ & 0.848 \\
\hline Selenium $(\mu \mathrm{g} / \mathrm{L})$ & $96.2 \pm 9.3$ & $98.6 \pm 9.1$ & 0.158 \\
\hline Zinc $(\mu \mathrm{mol} / \mathrm{L})$ & $15.0 \pm 3.0$ & $15.7 \pm 2.9$ & 0.159 \\
\hline Magnesium (mmol/L) & $15.0 \pm 8.7$ & $15.0 \pm 8.7$ & 0.786 \\
\hline Quercetin $(\mathrm{ng} / \mathrm{mL})$ & $13.9 \pm 7.0$ & $13.4 \pm 8.0$ & 0.727 \\
\hline
\end{tabular}

Values expressed as mean \pm S.D. RFS $=$ recommended food score.

Table 5 presents the effect of dietary supplementation with study samples on the change (delta) in blood nutrient status at Days 28 and 56 (baseline to Day 28 or 56). After 28 days of dietary VMP supplementation, RBC folate levels increased significantly from baseline and when compared to PLA $(3.40 \pm 5.88 \mu \mathrm{g} / \mathrm{L}$ and $0.71 \pm 5.86 \mu \mathrm{g} / \mathrm{L}$, respectively; $p<0.01)$. Serum Vit B6 levels decreased significantly from baseline at Day 28 in the PLA group and was significantly different than VMP group $(-4.58 \pm 6.48 \mu \mathrm{g} / \mathrm{L}$ and $-0.02 \pm 7.26 \mu \mathrm{g} / \mathrm{L}$, respectively; $p<0.001)$. Serum Vit B12 decreased significantly from baseline in both groups at Day 28.

After 56 days of dietary VMP supplementation, Vit $\mathrm{C}$ levels increased significantly from baseline and when compared to PLA $(8.21 \pm 9.27 \mathrm{mg} / \mathrm{dL}$ and $2.97 \pm 9.09 \mathrm{mg} / \mathrm{dL}$, respectively; $p<0.01)$ (Table 5). The change in RBC folate levels remained elevated from baseline in VMP group at Day 56, while levels did not change in PLA group $(3.20 \pm 7.18 \mu \mathrm{g} / \mathrm{L}$ and $-0.23 \pm 6.01 \mu \mathrm{g} / \mathrm{L}$, respectively, $p<0.003)$. Serum Vit B6 status continued to significantly decline from baseline in the PLA group $(-6.83 \pm 7.58 \mu \mathrm{g} / \mathrm{L})$, which was not observed in VMP group $(p=0.001)$. The decline in Vit B12 status from baseline persisted at Day 56 in PLA group $(-84 \pm 204 \mathrm{ng} / \mathrm{mL})$, while the VMP group seemed to partially recover from the initial declined seen at Day 28 (Table 5). Fifty-six days of dietary VMP supplementation significantly increased plasma quercetin compared to baseline, and when compared to PLA group $(4.28 \pm 8.58 \mathrm{ng} / \mathrm{mL}$ and $-0.08 \pm 9.45 \mathrm{ng} / \mathrm{mL}$, respectively; $p<0.005)$. 
Table 5. Change in blood nutrient status after 28 and 56 days of dietary supplementation.

\begin{tabular}{ccccc}
\hline Blood Nutrients & Intervention Period & PLA Group & VMP Group & $p$-Value $\ddagger$ \\
\hline$\beta$-Carotene $(\mu \mathrm{g} / \mathrm{dL})$ & Day 1-Day 28 & $11.02 \pm 41.44^{*}$ & $6.90 \pm 51.87$ & 0.684 \\
& Day 1-Day 56 & $0.00 \pm 54.70$ & $0.24 \pm 56.07$ & 0.491 \\
Total tocopherol $(\mathrm{mg} / \mathrm{dL})$ & Day 1-Day 28 & $-0.07 \pm 0.53$ & $0.06 \pm 0.63$ & 0.112 \\
& Day 1-Day 56 & $-0.06 \pm 0.55$ & $-0.01 \pm 0.57$ & 0.324 \\
Vit C $(\mathrm{mg} / \mathrm{dL})$ & Day 1-Day 28 & $0.36 \pm 10.28$ & $-0.99 \pm 8.76$ & 0.780 \\
& Day 1-Day 56 & $2.97 \pm 9.09$ & $8.21 \pm 9.27$ & 0.001 \\
RBC Folate $(\mu \mathrm{g} / \mathrm{L})$ & Day 1-Day 28 & $0.71 \pm 5.86$ & $3.40 \pm 5.88^{*}$ & 0.007 \\
& Day 1-Day 56 & $-0.23 \pm 6.01$ & $3.20 \pm 7.18$ & 0.003 \\
Vit B6 $(\mu \mathrm{g} / \mathrm{L})$ & Day 1-Day 28 & $-4.58 \pm 6.48^{*}$ & $-0.02 \pm 7.26$ & 0.0002 \\
& Day 1-Day 56 & $-6.83 \pm 7.58^{*}$ & $-2.46 \pm 7.87$ & 0.001 \\
Vit B12 $(\mathrm{ng} / \mathrm{mL})$ & Day 1-Day 28 & $-90 \pm 193^{*}$ & $-87 \pm 227 *$ & 0.470 \\
& Day 1-Day 56 & $-84 \pm 206^{*}$ & $-39 \pm 239$ & 0.136 \\
Zinc $(\mu \mathrm{mol} / \mathrm{L})$ & Day 1-Day 28 & $0.49 \pm 2.70$ & $-0.45 \pm 2.30$ & 0.978 \\
Selenium $(\mu \mathrm{g} / \mathrm{L})$ & Day 1-Day 56 & $-0.11 \pm 2.96$ & $-0.72 \pm 2.84$ & 0.872 \\
Quercetin $(\mathrm{ng} / \mathrm{mL})$ & Day 1-Day 28 & $1.60 \pm 9.07$ & $1.30 \pm 8.18$ & 0.575 \\
& Day 1-Day 56 & $1.23 \pm 7.99$ & $-0.40 \pm 10.09$ & 0.836 \\
\hline
\end{tabular}

Values expressed as mean \pm S.D. $\ddagger$ Between group comparison. ${ }^{*}$ Within group comparison $(p<0.05)$.

Table 6 shows the change on heart health biomarkers after 56 days of dietary supplementation with study samples. Serum Hcy levels decreased significantly from baseline in the VMP group and when compared to the PLA group $(-3.97 \pm 10.09 \mu \mathrm{mol} / \mathrm{L}$ and $-0.82 \pm 8.16 \mu \mathrm{mol} / \mathrm{L}$, respectively; $p=0.031$ ). Serum GGT levels were significantly reduced from baseline only in the VMP group and tended be to different compared to PLA group $(-1.68 \pm 14.53 \mathrm{U} / \mathrm{L}$ and $1.99 \pm 9.86 \mathrm{U} / \mathrm{L}$, respectively; $p=0.054)$. There were no significant effects on the lipid profile after dietary supplementation with study samples in either group (Table 6). There were no changes in blood chemistry and hematology measurements, and no AE reported during the study.

Table 6. Change in CVD biomarkers after 56 days of dietary supplementation.

\begin{tabular}{cccc}
\hline Heart Health Biomarkers & PLA Group & VMP Group & $p$-Value $\ddagger$ \\
\hline Hcy $(\mu \mathrm{mol} / \mathrm{L})$ & $-0.82 \pm 8.16$ & $-3.97 \pm 10.09^{*}$ & 0.031 \\
hs-CRP $(\mathrm{ng} / \mathrm{mL})$ & $515 \pm 2642$ & $134 \pm 3507$ & 0.251 \\
Oxidized LDL $(\mathrm{ng} / \mathrm{mL})$ & $1821 \pm 4172 *$ & $1907 \pm 4264^{*}$ & 0.544 \\
GGT $(\mathrm{U} / \mathrm{L})$ & $1.99 \pm 9.86$ & $-1.68 \pm 14.53^{*}$ & 0.054 \\
Uric acid $(\mu \mathrm{mol} / \mathrm{L})$ & $2.45 \pm 50.37$ & $-7.52 \pm 62.20$ & 0.168 \\
Total cholesterol $(\mathrm{mmol} / \mathrm{L})$ & $-0.18 \pm 0.93$ & $-0.16 \pm 0.82$ & 0.563 \\
HDL cholesterol $(\mathrm{mmol} / \mathrm{L})$ & $-0.08 \pm 0.34$ & $-0.04 \pm 0.33$ & 0.232 \\
LDL cholesterol $(\mathrm{mmol} / \mathrm{L})$ & $-0.17 \pm 0.79$ & $-0.12 \pm 0.76$ & 0.625 \\
Triglycerides $(\mathrm{mmol} / \mathrm{L})$ & $0.10 \pm 0.42$ & $0.02 \pm 0.44$ & 0.159
\end{tabular}

Values expressed as mean \pm S.D. $\ddagger$ Between group comparison. ${ }^{*}$ Within group comparison $(p<0.05)$; $\mathrm{CVD}=$ cardiovascular disease

\section{Discussion}

This is the first randomized, double blind placebo, controlled study investigating the effect of the vitamin-mineral complex with phytonutrients on nutrient status and biomarkers of heart health risk factors in a generally healthy adult Russian population. There were three main categories of outcome measures examined in the clinical study: (1) plasma levels of water-soluble antioxidants (i.e., Vit $C$ and quercetin) and fat-soluble antioxidants (i.e., $\beta$-carotene); (2) circulating levels of the "anti-homocysteine triad", Vit B6, Vit B12 and RBC folate; and (3) biomarkers associated with heart health such (i.e., serum Hcy and GGT). The key findings of this study were that a dietary VMP supplementation (Nutrilite Double $\mathrm{X}^{\mathrm{TM}}$ ) improved overall Vit B status and reduced serum Hcy levels compared to PLA group. 
It was not surprising that, among randomized subjects, women were predominant, as, according to many studies, women practiced more healthy habits and had a higher dietary supplement intake rate than men [24-26]. Moreover, this gender difference in dietary supplement consumption is more prominent in younger age and disappears after six/seven decade of life [27]. All subjects included the study had low consumption of fruits and vegetables based on the modified Recommended Foods Checklist. This is in line with previously reported fruit and vegetable intake in this population, and is far from the $400 \mathrm{~g} /$ day recommended by WHO. Low consumption of fruits and vegetables is also recognized as CVD risk factor, and enriching the diet with fruits and vegetables is considered as one of the effective tools for CVD prophylaxis [28,29].

Low folate status is associated with an increased CVD risk [30,31]. One mechanism by which folate (and overall $\mathrm{B}$ vitamins) has been shown to be protective in the development of CVD is by reducing serum Hcy levels. B vitamins, specifically folate, B6 and B12 are essential for recycling of Hcy back to methionine or for cysteine synthesis. If Hcy is not properly recycled, elevated levels have been reported to cause an increased risk for developing CVD and other age-related diseases [32-36]. In healthy populations, the main nutritional cause of elevated blood Hcy is folate deficiency, which appears to be the case for the subjects in this study. Furthermore, low Vit B12 status has been reported to be a reliable surrogate marker of elevated Hcy [37]. The low overall B vitamin status that was observed in the PLA group during the 56 days trial is in line with previous reports on Russian urban population [38]. Dietary supplementation with folate and B vitamins or food fortification is a first line treatment for elevated Hcy levels, as at least $0.8 \mathrm{mg} /$ day of folate is necessary to achieve the maximal reduction of Hcy [39]. Therefore, increasing folate (and overall B vitamins) status, similar to what was achieved in the VMP supplemented group, may translate into benefits of reducing CVD risk if subjected continued supplementation, but this needs to be proved in long-term prospective controlled trials.

Serum hs-CRP is considered a biomarker of CVD risk; however, levels were not significantly influenced by the VMP supplementation. In several population-based studies, blood level of hs-CRP correlated with blood pressure, age, blood glucose level and BMI [40,41], which are established CVD risk factors. In addition, a chronic, continuous elevation in hs-CRP has been reported to be a more relevant CVD risk than the high level found in one measurement [42]. hs-CRP is a marker of systemic inflammation (both acute and chronic), which can change in both directions depending on the inflammation course. Therefore, it is not surprising that during the short duration of our study we found high variability in hs-CRP levels and no significant changes after the dietary supplementation.

Free radicals or reactive oxygen species (ROS) are generated by normal energy metabolism and are controlled by antioxidant pathways. When there is insufficient removal of these ROS, the oxidative damage can increase the risk of CVD development $[43,44]$. Both Vit $C$ and quercetin are known to be effective antioxidants. Quercetin is one of the most abundant flavonoid found in fruits, vegetables, leaves and grains, and is widely used as a dietary supplement in the food industry. Quercetin has been reported to modulation various of biological pathways, including cellular signaling events implicated in CVD development [45-48]. In a population that consumes low levels of fruits and vegetables, the higher plasma Vit $C$ and quercetin levels found after the VMP supplementation could contribute to a lower risk of developing CVD if one was to chronically consume these antioxidants.

Vit $\mathrm{C}$ and polyphenols (flavonoids and non-flavonoids) are major natural antioxidants capable of preventing damage generated by oxidative stress [49]. It is possible that these benefits observed with VMP supplementation could be due to the combination of multiple vitamins, minerals and/or polyphenols, such as quercetin. Quercetin was reported to reduce Hcy by increasing remethylation and transsulfuration of homocysteine in rats [50]. Moreover, the combination of quercetin and Vit C seems to protect against oxidative stress by enhancing regeneration of endogenous antioxidants such as glutathione peroxidase, which might reduce deleterious effects of ROS [51]. This would suggest that the combination might stimulate synergistic response greater than individual antioxidant.

Recent meta-analysis showed that GGT activity is strongly associated with CVD risk in the general population [52]. Moreover, a longitudinal increase in GGT, independent of baseline level and even 
within its normal range, significantly increased risk of fatal CVD [53]. Therefore, reduction of GGT may reflect the reduction of CVD risk. In this study, the level of GGT was within normal range at baseline in all participants, but a greater reduction of GGT level was found in the VMP group compared to the PLA group. It is interesting to note that subjects in the VMP group with higher baseline GGT values showed a significantly more pronounced decrease in their GGT values as compared to the PLA group subjects with higher baseline GGT values.

The limitation of our study is the short duration of the intervention and unbalanced gender ratio; therefore, we can use only surrogate markers of CVD risk. Two large RCT in which total mortality and CVD mortality were used as outcomes did not confirm any influence of long-term (11 and 7.5 years) use of multivitamin or antioxidant supplements on the number of CVD events or CVD related mortality [54,55]. However, blood levels of vitamins and antioxidants were not controlled in these studies and the compliance was accessed through questionnaire and telephone surveys. Moreover, in one of the studies, only men were enrolled; therefore, gender analysis of the results was not possible. On the contrary, a retrospective epidemiological study showed that use of multivitamin-mineral supplements for $\geq 3$ years was associated with reduced risk of CVD mortality among women when models controlled for age, race, education, body mass index, alcohol, aspirin use, serum lipids, blood pressure and blood glucose/glycated hemoglobin [56]. These findings were confirmed by the results of a Swedish study in which the use of multivitamins was associated with reduced risk of myocardial infarction, and this reduction was even greater if women used supplements for $\geq 5$ years [57]. Our study demonstrated that short-term use of VMP leads to changes in circulating antioxidants and biomarkers of CVD risk in a Russian population. However, to confirm whether these effects translate into reduced CVD mortality, large, long-term controlled studies are needed.

\section{Conclusions}

Dietary VMP supplementation improved the nutrient status and reduced biomarkers of heart health risk (Hcy and GGT) in a Russian population.

Acknowledgments: Authors would like to thank Anatoly Kutyshenko and Elena Pletneva for their assistance.

Author Contributions: Employees of Access Business Group International, LLC and the Russia Institute of Nutrition had a role in the design of these experiments and the interpretation of the data. Y.L. and V.A.I. developed the study design. Y.L., V.A.I., A.A.B., V.V.B., T.B.S. and V.A.T. executed the trial and biochemical measurements. Y.L., V.K. and V.A.I. performed data analysis. J.H. and R.A.V. prepared and wrote manuscript. All authors participated in drafting of the manuscript and final approval.

Conflicts of Interest: The source of funding was Access Business Group International, LLC. Y.L. was an employee of Access Business Group International, LLC during the conduction of this study, V.K., J.H. and R.A.V. are employees of Access Business Group International, LLC. V.A.I., A.A.G., V.V.B., T.B.S. and V.A.T. declare no conflict of interest.

\section{Appendix A}

The list of 23 foods used to calculate the RFS. One point is given for each item below if subjects recalled eating them at least once a week.

Apples/pears; Baked or broiled fish; Baked or stewed chicken or turkey; Baked or stewed chicken or turkey; Black currants; Broccoli; Carrots or mixed vegetables with carrots; Cooked cereals; Dark bread; Grapefruit; Green salad; High fiber/bran/granola cereals; Marrow; Orange/grapefruit juice; Oranges; Other fruit juices; Paprica; Potato; $\%$ milk; Skim or 1\% milk; Spinach; Spring (sprout) onion; Tomatoes; White cabbage.

\section{References}

1. Zhang, D.; Cogswell, M.E.; Wang, G.; Bowman, B.A. Evidence of dietary improvement and preventable costs of cardiovascular disease. Am. J. Cardiol. 2017, 120, 1681-1688. [CrossRef] [PubMed] 
2. $\quad$ Egert, S.; Bosy-Westphal, A.; Seiberl, J.; Kurbitz, C.; Settler, U.; Plachta-Danielzik, S.; Wagner, A.E.; Frank, J.; Schrezenmeir, J.; Rimbach, G.; et al. Quercetin reduces systolic blood pressure and plasma oxidised low-density lipoprotein concentrations in overweight subjects with a high-cardiovascular disease risk phenotype: A double-blinded, placebo-controlled cross-over study. Br. J. Nutr. 2009, 102, 1065-1074. [CrossRef] [PubMed]

3. Jagtap, S.; Meganathan, K.; Wagh, V.; Winkler, J.; Hescheler, J.; Sachinidis, A. Chemoprotective mechanism of the natural compounds, epigallocatechin-3-o-gallate, quercetin and curcumin against cancer and cardiovascular diseases. Curr. Med. Chem. 2009, 16, 1451-1462. [CrossRef] [PubMed]

4. Patel, H.; Chandra, S.; Alexander, S.; Soble, J.; Williams, K.A., Sr. Plant-based nutrition: An essential component of cardiovascular disease prevention and management. Cur. Cardiol. Rep. 2017, 19, 104. [CrossRef] [PubMed]

5. Assies, J.; Mocking, R.J.; Lok, A.; Ruhe, H.G.; Pouwer, F.; Schene, A.H. Effects of oxidative stress on fatty acidand one-carbon-metabolism in psychiatric and cardiovascular disease comorbidity. Acta Psychiatr. Scand. 2014, 130, 163-180. [CrossRef] [PubMed]

6. Ventura, E.; Durant, R.; Jaussent, A.; Picot, M.C.; Morena, M.; Badiou, S.; Dupuy, A.M.; Jeandel, C.; Cristol, J.P. Homocysteine and inflammation as main determinants of oxidative stress in the elderly. Free Radic. Biol. Med. 2009, 46, 737-744. [CrossRef] [PubMed]

7. Lai, W.K.; Kan, M.Y. Homocysteine-induced endothelial dysfunction. Ann. Nutr. Metab. 2015, 67, 1-12. [CrossRef] [PubMed]

8. Jansen, E.; Beekhof, P.; Tamosiunas, A.; Luksiene, D.; Baceviciene, M. Biomarkers of oxidative stress and redox status in a short-term low-dosed multivitamin and mineral supplementation study in two human age groups. Biogerontology 2015, 16, 645-653. [CrossRef] [PubMed]

9. Waskiewicz, A.; Sygnowska, E.; Broda, G. Dietary intake of vitamins b6, b12 and folate in relation to homocysteine serum concentration in the adult polish population-Wobasz project. Kardiol. Pol. 2010, 68, 275-282. [PubMed]

10. Ciaccio, M.; Bellia, C. Hyperhomocysteinemia and cardiovascular risk: Effect of vitamin supplementation in risk reduction. Curr. Clin. Pharmacol. 2010, 5, 30-36. [CrossRef] [PubMed]

11. Jain, A.; Agrawal, B.K.; Varma, M.; Jadhav, A.A. Antioxidant status and smoking habits: Relationship with diet. Singap. Med. J. 2009, 50, 624-627.

12. Bloomer, R.J. Decreased blood antioxidant capacity and increased lipid peroxidation in young cigarette smokers compared to nonsmokers: Impact of dietary intake. Nutr. J. 2007, 6, 39. [CrossRef] [PubMed]

13. Sasaki, S. Alcohol and its relation to all-cause and cardiovascular mortality. Acta Cardiol. 2000, 55, $151-156$. [CrossRef] [PubMed]

14. Zabina, H.; Schmid, T.L.; Glasunov, I.; Potemkina, R.; Kamardina, T.; Deev, A.; Konstantinova, S.; Popovich, M. Monitoring behavioral risk factors for cardiovascular disease in Russia. Am. J. Public Health 2001, 91, 1613-1614. [CrossRef] [PubMed]

15. Margetts, B. Fao/who launch expert report on diet, nutrition and prevention of chronic diseases. Public Health Nutr. 2003, 6, 323-325. [CrossRef] [PubMed]

16. Hall, J.N.; Moore, S.; Harper, S.B.; Lynch, J.W. Global variability in fruit and vegetable consumption. Am. J. Prev. Med. 2009, 36, 402-409. [CrossRef] [PubMed]

17. Goryakin, Y.; Rocco, L.; Suhrcke, M.; Roberts, B.; McKee, M. Fruit and vegetable consumption in the former soviet union: The role of individual- and community-level factors. Public Health Nutr. 2015, 18, 2825-2835. [CrossRef] [PubMed]

18. Zhang, Y.J.; Gan, R.Y.; Li, S.; Zhou, Y.; Li, A.N.; Xu, D.P.; Li, H.B. Antioxidant phytochemicals for the prevention and treatment of chronic diseases. Molecules 2015, 20, 21138-21156. [CrossRef] [PubMed]

19. Kant, A.K.; Schatzkin, A.; Graubard, B.I.; Schairer, C. A prospective study of diet quality and mortality in women. JAMA 2000, 283, 2109-2115. [CrossRef] [PubMed]

20. Blokhina, L.V.; Kondakova, N.M.; Pogozheva, A.V.; Baturin, A.K. Multilevel study of actual nutrition in the complex analysis of nutritial status of patients with obesity. Voprosy Pitaniia 2009, 78, 35-39. [PubMed]

21. Thibeault, D.; Su, H.; MacNamara, E.; Schipper, H.M. Isocratic rapid liquid chromatographic method for simultaneous determination of carotenoids, retinol, and tocopherols in human serum. J. Chromatogr. B Analyt. Technol. Biomed. Life Sci. 2009, 877, 1077-1083. [CrossRef] [PubMed] 
22. Sheehan, T.M.; Gao, M. Simplified fluorometric assay of total selenium in plasma and urine. Clin. Chem. 1990, 36, 2124-2126. [PubMed]

23. Stracke, B.A.; Rufer, C.E.; Bub, A.; Seifert, S.; Weibel, F.P.; Kunz, C.; Watzl, B. No effect of the farming system (organic/conventional) on the bioavailability of apple (malus domestica bork., cultivar golden delicious) polyphenols in healthy men: A comparative study. Eur. J. Nutr. 2010, 49, 301-310. [CrossRef] [PubMed]

24. Kim, J.W.; Lee, S.H.; Kim, J.E.; Han, K.D.; Kwack, T.E.; Kim, B.S.; Kim, J.E.; Jo, E.B.; Park, Y.K.; Lee, K.S. The association between taking dietary supplements and healthy habits among korean adults: Results from the fifth korea national health and nutritional examination survey (2010-2012). Korean J. Fam. Med. 2016, 37, 182-187. [CrossRef] [PubMed]

25. Rock, C.L. Multivitamin-multimineral supplements: Who uses them? Am. J. Clin. Nutr. 2007, 85, 277S-279S. [PubMed]

26. Reinert, A.; Rohrmann, S.; Becker, N.; Linseisen, J. Lifestyle and diet in people using dietary supplements: A german cohort study. Eur. J. Nutr. 2007, 46, 165-173. [CrossRef] [PubMed]

27. Tetens, I.; Biltoft-Jensen, A.; Spagner, C.; Christensen, T.; Gille, M.B.; Bugel, S.; Banke Rasmussen, L. Intake of micronutrients among Danish adult users and non-users of dietary supplements. Food Nutr. Res. 2011, 55, 7153. [CrossRef] [PubMed]

28. Getz, G.S.; Reardon, C.A. Nutrition and cardiovascular disease. Arterioscler. Thromb. Vasc. Biol. 2007, 27, 2499-2506. [CrossRef] [PubMed]

29. Graham, I.; Atar, D.; Borch-Johnsen, K.; Boysen, G.; Burell, G.; Cifkova, R.; Dallongeville, J.; De Backer, G.; Ebrahim, S.; Gjelsvik, B.; et al. European guidelines on cardiovascular disease prevention in clinical practice: Executive summary. Atherosclerosis 2007, 194, 1-45. [CrossRef] [PubMed]

30. Loria, C.M.; Ingram, D.D.; Feldman, J.J.; Wright, J.D.; Madans, J.H. Serum folate and cardiovascular disease mortality among us men and women. Arch. Intern. Med. 2000, 160, 3258-3262. [CrossRef] [PubMed]

31. Porter, K.; Hoey, L.; Hughes, C.F.; Ward, M.; McNulty, H. Causes, consequences and public health implications of low b-vitamin status in ageing. Nutrients 2016, 8, 725. [CrossRef] [PubMed]

32. Barron, E.; Lara, J.; White, M.; Mathers, J.C. Blood-borne biomarkers of mortality risk: Systematic review of cohort studies. PLoS ONE 2015, 10, e0127550. [CrossRef] [PubMed]

33. Morris, M.S. Folate, homocysteine, and neurological function. Nutr. Clin. Care 2002, 5, 124-132. [CrossRef] [PubMed]

34. Dong, C.; Yoon, W.; Goldschmidt-Clermont, P.J. DNA methylation and atherosclerosis. J. Nutr. 2002, 132, 2406S-2409S. [CrossRef] [PubMed]

35. Mattson, M.P.; Shea, T.B. Folate and homocysteine metabolism in neural plasticity and neurodegenerative disorders. Trends Neurosci. 2003, 26, 137-146. [CrossRef]

36. Tracy, R.P. Emerging relationships of inflammation, cardiovascular disease and chronic diseases of aging. Int. J. Obes. Relat. Metab. Disord. 2003, 27 (Suppl. 3), S29-S34. [CrossRef] [PubMed]

37. Parnetti, L.; Bottiglieri, T.; Lowenthal, D. Role of homocysteine in age-related vascular and non-vascular diseases. Aging Clin. Exp. Res. 1997, 9, 241-257. [CrossRef]

38. Beketova, N.A.; Spiricheva, T.V.; Pereverzeva, O.G.; Kosheleva, O.V.; Brzhesinskaia, O.A.; Kharitonchik, L.A.; Kodentsova, V.M.; Spirichev, V.B. The influence of age and sex on fat- and water-soluble vitamins sufficiency of adulthood. Voprosy Pitaniia 2009, 78, 53-59. [PubMed]

39. McNulty, H.; Pentieva, K.; Hoey, L.; Ward, M. Homocysteine, b-vitamins and cvd. Proc. Nutr. Soc. 2008, 67, 232-237. [CrossRef] [PubMed]

40. Wang, Z.; Wang, X.; Chen, Z.; Zhang, L.; Zhu, M. Distribution of high-sensitivity c-reactive protein and its relationship with other cardiovascular risk factors in the middle-aged chinese population. Int. J. Environ. Res. Public Health 2016, 13, 872. [CrossRef] [PubMed]

41. Vu, T.H.; Liu, K.; Lloyd-Jones, D.M.; Stamler, J.; Pirzada, A.; Shah, S.J.; Garside, D.B.; Daviglus, M.L. Favorable levels of all major cardiovascular risk factors at younger ages and high-sensitivity c-reactive protein 39 years later-The Chicago healthy aging study. Prev. Med. Rep. 2015, 2, 235-240. [CrossRef] [PubMed]

42. Wang, A.; Liu, J.; Li, C.; Gao, J.; Li, X.; Chen, S.; Wu, S.; Ding, H.; Fan, H.; Hou, S. Cumulative exposure to high-sensitivity c-reactive protein predicts the risk of cardiovascular disease. J. Am. Heart Assoc. 2017, 6, e005610. [CrossRef] [PubMed] 
43. Zhang, P.Y.; Xu, X.; Li, X.C. Cardiovascular diseases: Oxidative damage and antioxidant protection. Eur. Rev. Med. Pharmacol. Sci. 2014, 18, 3091-3096. [PubMed]

44. Farias, J.G.; Molina, V.M.; Carrasco, R.A.; Zepeda, A.B.; Figueroa, E.; Letelier, P.; Castillo, R.L. Antioxidant therapeutic strategies for cardiovascular conditions associated with oxidative stress. Nutrients 2017, 9, 966. [CrossRef] [PubMed]

45. Ibarra, M.; Moreno, L.; Vera, R.; Cogolludo, A.; Duarte, J.; Tamargo, J.; Perez-Vizcaino, F. Effects of the flavonoid quercetin and its methylated metabolite isorhamnetin in isolated arteries from spontaneously hypertensive rats. Planta Medica 2003, 69, 995-1000. [PubMed]

46. Ajay, M.; Achike, F.I.; Mustafa, A.M.; Mustafa, M.R. Effect of quercetin on altered vascular reactivity in aortas isolated from streptozotocin-induced diabetic rats. Diabetes Res. Clin. Pract. 2006, 73, 1-7. [CrossRef] [PubMed]

47. Williams, R.J.; Spencer, J.P.; Rice-Evans, C. Flavonoids: Antioxidants or signalling molecules? Free Radic. Biol. Med. 2004, 36, 838-849. [CrossRef] [PubMed]

48. Marunaka, Y.; Marunaka, R.; Sun, H.; Yamamoto, T.; Kanamura, N.; Inui, T.; Taruno, A. Actions of quercetin, a polyphenol, on blood pressure. Molecules 2017, 22, 209. [CrossRef] [PubMed]

49. Djeffal, A.; Messarah, M.; Boumendjel, A.; Kadeche, L.; Feki, A.E. Protective effects of vitamin c and selenium supplementation on methomyl-induced tissue oxidative stress in adult rats. Toxicol. Ind. Health 2015, 31, 31-43. [CrossRef] [PubMed]

50. Meng, B.; Gao, W.; Wei, J.; Pu, L.; Tang, Z.; Guo, C. Quercetin increases hepatic homocysteine remethylation and transsulfuration in rats fed a methionine-enriched diet. BioMed Res. Int. 2015, 2015, 815210. [CrossRef] [PubMed]

51. Paunovic, M.G.; Ognjanovic, B.I.; Matic, M.M.; Stajn, A.S.; Saicic, Z.S. Protective effects of quercetin and vitamin c against nicotine-induced toxicity in the blood of wistar rats. Arhiv za Higijenu Rada i Toksikologiju 2016, 67, 304-310. [CrossRef] [PubMed]

52. Kunutsor, S.K.; Apekey, T.A.; Khan, H. Liver enzymes and risk of cardiovascular disease in the general population: A meta-analysis of prospective cohort studies. Atherosclerosis 2014, 236, 7-17. [CrossRef] [PubMed]

53. Strasak, A.M.; Kelleher, C.C.; Klenk, J.; Brant, L.J.; Ruttmann, E.; Rapp, K.; Concin, H.; Diem, G.; Pfeiffer, K.P.; Ulmer, H.; et al. Longitudinal change in serum gamma-glutamyltransferase and cardiovascular disease mortality: A prospective population-based study in 76,113 austrian adults. Arterioscler. Thromb. Vasc. Biol. 2008, 28, 1857-1865. [CrossRef] [PubMed]

54. Sesso, H.D.; Christen, W.G.; Bubes, V.; Smith, J.P.; MacFadyen, J.; Schvartz, M.; Manson, J.E.; Glynn, R.J.; Buring, J.E.; Gaziano, J.M. Multivitamins in the prevention of cardiovascular disease in men: The physicians' health study ii randomized controlled trial. JAMA 2012, 308, 1751-1760. [CrossRef] [PubMed]

55. Hercberg, S.; Galan, P.; Preziosi, P.; Bertrais, S.; Mennen, L.; Malvy, D.; Roussel, A.M.; Favier, A.; Briancon, S. The su.Vi.Max study: A randomized, placebo-controlled trial of the health effects of antioxidant vitamins and minerals. Arch. Intern. Med. 2004, 164, 2335-2342. [CrossRef] [PubMed]

56. Bailey, R.L.; Fakhouri, T.H.; Park, Y.; Dwyer, J.T.; Thomas, P.R.; Gahche, J.J.; Miller, P.E.; Dodd, K.W.; Sempos, C.T.; Murray, D.M. Multivitamin-mineral use is associated with reduced risk of cardiovascular disease mortality among women in the united states. J. Nutr. 2015, 145, 572-578. [CrossRef] [PubMed]

57. Rautiainen, S.; Akesson, A.; Levitan, E.B.; Morgenstern, R.; Mittleman, M.A.; Wolk, A. Multivitamin use and the risk of myocardial infarction: A population-based cohort of Swedish women. Am. J. Clin. Nutr. 2010, 92, 1251-1256. [CrossRef] [PubMed]

(C) 2018 by the authors. Licensee MDPI, Basel, Switzerland. This article is an open access article distributed under the terms and conditions of the Creative Commons Attribution (CC BY) license (http://creativecommons.org/licenses/by/4.0/). 